\title{
Effect of clone selection, nitrogen supply, leaf damage and mycorrhizal fungi on stilbene and emodin production in knotweed
}

\author{
Marcela Kovářová ${ }^{*}$, Tomáš Frantík', Helena Koblihová1, Kristýna Bartůňková', Zora Nývltová and \\ Miroslav Vosátka ${ }^{1}$
}

\begin{abstract}
Background: Fallopia japonica and its hybrid, F. xbohemica, due to their fast spread, are famous as nature threats rather than blessings. Their fast growth rate, height, coverage, efficient nutrient translocation between tillers and organs and high phenolic production, may be perceived either as dangerous or beneficial features that bring about the elimination of native species or a life-supporting source. To the best of our knowledge, there have not been any studies aimed at increasing the targeted production of medically desired compounds by these remarkable plants. We designed a two-year pot experiment to determine the extent to which stilbene (resveratrol, piceatannol, resveratrolosid, piceid and astringins) and emodin contents of F. japonica, F. sachalinensis and two selected F. xbohemica clones are affected by soil nitrogen ( $N$ ) supply, leaf damage and mycorrhizal inoculation.

Results: 1) Knotweeds are able to grow on substrates with extremely low nitrogen content and have a high efficiency of $\mathrm{N}$ translocation. The fast-spreading hybrid clones store less $\mathrm{N}$ in their rhizomes than the parental species. 2) The highest concentrations of stilbenes were found in the belowground biomass of F. japonica. However, because of the high belowground biomass of one clone of $F$. xbohemica, this hybrid produced more stilbenes per plant than F. japonica. 3) Leaf damage increased the resveratrol and emodin contents in the belowground biomass of the non-inoculated knotweed plants. 4) Although knotweed is supposed to be a nonmycorrhizal species, its roots are able to host the fungi. Inoculation with mycorrhizal fungi resulted in up to $2 \%$ root colonisation. 5) Both leaf damage and inoculation with mycorrhizal fungi elicited an increase of the piceid (resveratrol-glucoside) content in the belowground biomass of F. japonica. However, the mycorrhizal fungi only elicited this response in the absence of leaf damage. Because the leaf damage suppressed the effect of the root fungi, the effect of leaf damage prevailed over the effect of the mycorrhizal fungi on the piceid content in the belowground biomass.
\end{abstract}

Conclusions: Two widely spread knotweed species, F. japonica and F. xbohemica, are promising sources of compounds that may have a positive impact on human health. The content of some of the target compounds in the plant tissues can be significantly altered by the cultivation conditions including stress imposed on the plants, inoculation with mycorrhizal fungi and selection of the appropriate plant clone.

Keywords: Fallopia, F. xbohemica, F. xjaponica, F. xsachalinensis, Polygonaceae, Reynoutria, knotweed, emodin, stilbenes, piceid, resveratrol, leaf damage, mycorrhiza

\footnotetext{
* Correspondence: marcela.kovarova@ibot.cas.cz

${ }^{1}$ Institute of Botany, Czech Academy of Science, Průhonice 1, 252 43, Czech

Republic

Full list of author information is available at the end of the article
} 


\section{Background}

In the Czech Republic, the genus Fallopia Adans. (Polygonaceae), also reported as a separate genus Reynoutria (Houtt.) Ronse Decr. consists of two species - F. japonica (Houtt.) Ronse Decr. (Japanese knotweed) and $F$. sachalinensis (F. Schmidt Petrop.) Ronse Decr. (Giant knotweed), and their hybrid, F. xbohemica (Chrtek et Chrtková) J. P. Bailey. The hybrid appeared when the two parental species, introduced into Europe from Asia in the $19^{\text {th }}$ century [1] as garden ornamentals, came into contact $[1,2]$. These perennial herbs are highly invasive, exotic species and recognized as a major environmental management problem in Europe [3,4] including Czech Republic [5]. However they also produce nectar and a plethora of organic substances that may be harvested for medicinal use [6]. Their use has not been only as melliferous or medical, but also as energetic plants (gross heating value comparable to that of wood, $18.4 \mathrm{GJ} \cdot \mathrm{t}^{-1}$ ) with high growth rate and biomass production [7]. The knotweeds are utilized as a cultivated crop under rigid regulations in the Czech Republic $[7,8]$. Knotweeds are also used for soil amelioration, sewage treatment (because of its ability to accumulate heavy metals, especially $\mathrm{Cd}$ and $\mathrm{Pb}$ ) and riverbank and sand hill reinforcement [7]. However, these qualities also contribute to its competitive advantage over other plants and result in monospecific stands, which are undesirable in nature reserves. There have been attempts to eradicate it by use of a glyphosate herbicide, combined with physical removal of the plants including sheep grazing, which was most efficient http://www.pod.cz/projekty/Moravkakridlatka/Zaklnformace/metodikarev2602.pdf Herbicide treatment is, however, questionable as glyphosates contain phosphorus and may act as fertilizers enhancing knotweed growth especially on phosphorus-deficient soils.

Knotweed species differ in their clonal architecture, morphological and ecological properties. F. xbohemica has a high regeneration potential and a number of clones of the hybrid can be considered as the most successful representatives of the genus in terms of growth rate, regeneration and the establishment of new shoots. The species $F$. sachalinensis has the lowest regeneration ability [2,9]. Fallopia spp. also differ in their relative abundance in the Czech landscape [1], the hybrid is most widespread.

Knotweeds grow as pioneer species on volcanic soils [10-12] and coal ashes produced by power plants. Therefore, because of the very low $\mathrm{N}$ content in these substrates, they may be suitable for testing the effect of nitrogen content on the production of stilbenes (resveratrol) and emodin used in the pharmaceutical and food industries. There is evidence that secondary metabolites are produced in greater amounts in plants growing in low-nitrogen soils, because phenylalanine formed by photosynthesis is converted into phenolics under low $\mathrm{N}$ conditions [13]. However, under high $\mathrm{N}$ conditions phenylalanine is assimilated into proteins [14]. For these reasons, we selected ash as a model substrate in this experiment.

The pharmaceutical uses for knotweed have focused on stilbenes (resveratrol, piceatannol and their glucosides, piceid, resveratrolosid and astringins) and emodin. Resveratrol-glucosides (e.g., piceid) can be split into glucose and resveratrol, which increases the resveratrol levels. Therefore, we monitored the full range of resveratrol-containing substances, besides emodin.

Emodin is a biologically active, naturally occurring anthraquinone derivative (1,3,8-trihydroxy-6-methylanthraquinone) that is produced by lichens, fungi and higher plants that possess purgative, anti-inflammatory and anticancer effects [15-18]. In addition, emodin has been shown to induce apoptosis [19]. Resveratrol (3,4',5trihydroxystilbene; molecular weight $228.2 \mathrm{~g} / \mathrm{mol}$ ) is a naturally occurring polyphenol that is present in various fruits and vegetables in significant levels. It has been shown to have antibacterial [20,21], antifungal [22], antioxidant, antimutagenic, anti-inflammatory, chemopreventive [23,24] and anticancer effects [25-27] including the inhibition of breast cancer [28]. It also inhibits $\alpha$ glucosidase which is promising for the control of diabetes [29]. Knotweed is traditionally used for the production of resveratrol in Asia, particularly in China. In Europe, wine is the main source of this substance. A variety of stilbenes have been found in wine, including astringin, cis- and trans-piceid and cis- and transresveratrol.

Fungi (Botrytis cinerea) have been reported to increase the resveratrol content in wine grapes or in the leaves as a possible plant response to stress $[24,30,31]$. Resveratrol has antifungal activity and can restrict growth of Trichosporon beigelii, Candida albicans [22], Penicillium expansum, Aspergillus niger [32] and A. carbonarius [33]. Specifically it was found that $90 \mu \mathrm{g} \cdot \mathrm{ml}^{-1}$ of resveratrol reduced mycelial growth and the germination of $B$. cinerea conidia by $50 \%$ [34].

Some plants are known to possess advantageous features, such as mycorrhizal symbiosis, that enable them to overcome the challenges in their environment in harsh conditions. However, some plants react to the same mycorrhizal fungi adversely - namely plants that do not host mycorrhizal fungi, including all of the members of the family Polygonaceae, such as Fallopia [35]. Although knotweed is supposed to be a non-mycorrhizal plant, an arbuscular type of mycorrhiza was found in the roots of knotweeds growing in the volcanic soils of Mt. Fuji, Japan [12]. In addition, we found mycorrhizal colonisation in the roots of knotweeds sampled from a 
flooded alder forest in Moravia (Rydlová, personal communication). Therefore, mycorrhizal fungi may associate with knotweeds and potentionally alter their growth characteristics, their genotype and accumulation of plant secondary compounds [36]. Synthesis of resveratrol and its derivatives, especially piceid, is regulated by stilbene synthase (STS) gene which typically occurs in grapevines $[37,38]$, wherefrom it was also transduced into different crop plants with the aim to increase their resistance against pathogens. STS gene is a typical stress-inducible/responsive gene. Fungi, not only pathogens but also mycorrhizal ones, belong to the stressors capable of induction of such responses in plant cells like chromatin decondensation enabling, besides others, gene expression [39]. It is thus to be expected that mycorrhizal colonization of knotweed roots may also induce STS gene expression in this plant, resulting in synthesis of resveratrol and its derivatives, namely piceid [40]. We thus chose to inoculate knotweeds with mycorrhizal fungi (a mixture of Glomus species) as a factor expected to increase the yield of these economically valuable compounds.

It has been reported that simulating herbivore (insect) grazing can increase the production of phenolic compounds in these plants [41]. Therefore, we exposed the knotweed plants to leaf damage to investigate if they would respond by increasing the production of stilbenes and emodin. In addition to studying the potential of traditional source of resveratrol in Fallopia japonica, we also wanted to study the "inland" sources of resveratrol and other stilbenes in F. xbohemica, along with the other parental species, F. sachalinensis. The resveratrol and piceid contents in these plants, in terms of dry mass, have not been discussed in the current literature. This study constitutes a novel contribution to the production of stilbenes and emodin in knotweeds. We use the term stilbenes for the sum of resveratrol and resveratrol contained in all its derivatives measured (piceatannol, piceid, resveratrolosid and astringins).

It can be expected that related taxa may respond differently to the same conditions. The present study compared the responses of two clones of the hybrid, along with its parental species. The following questions were addressed:

(1) How do the different species and clones of knotweed respond to soil nitrogen contents, in terms of stilbene and emodin production? (2) What is the effect of mycorrhizal inoculation/colonisation? (3) What is the effect of leaf damage to the individual species/clones on the production of stilbenes and emodin?

\section{Results}

The biomass and chemical characteristics measured and tested by ANOVA are shown in Table 1. F-values and degrees of freedom may be found in Table S3 in Additional file 1. Only the three clones (FJ, FBM and FBP; for symbols see Methods) that contained stilbenes and emodin in higher concentrations were analysed for organic substances.

\section{Differences between clones at two nitrogen levels Biomass}

The aboveground biomasses (Figure 1a) of the clones differed and the pattern of the values was constant under lower and higher soil $\mathrm{N}$ levels in 2007. The lowest aboveground biomass was produced by FJ, followed by FBP. FBM and FS produced the highest biomass. Similar differences between the clones were measured in 2006 as well. FJ and FS produced the lowest belowground biomass, whereas FBM produced the highest biomass at both soil $\mathrm{N}$ levels (Figure $1 \mathrm{~b}$ ). As expected, the higher soil nitrogen supply increased the biomass of all of the clones.

\section{Mycorrhizal colonisation}

No colonisation by mycorrhizal fungi was found in the roots of the non-inoculated plants. In the inoculated plants, vesicles and internal hyphae were present in the roots; however, arbuscules were not. Figure 2 shows that the inoculated plants developed very low intensity of mycorrhizal colonisation (M). FS had the lowest $M$ value (with no mycorrhizal colonisation), whereas FJ had the highest $M$ value and was the best host for the mycorrhizal fungi. The $M$ values for the two hybrid clones fell in between the parents. The effect of nitrogen on mycorrhizal colonisation was not significant. The trend of the frequency of mycorrhizal colonisation (F) was similar to that of the $M$ values and is not shown here.

\section{Nitrogen Content in Plant Biomass}

When the data for all the clones were combined, the higher soil $\mathrm{N}$ level was reflected in the higher $\mathrm{N}$ content of the belowground biomass (Table 1). However, the individual clones did not show a statistically significant increase between the lower and higher $\mathrm{N}$ levels (Figure 3).

There were differences in the $\mathrm{N}$ content of the belowground biomass at the two levels of soil nitrogen content studied between the particular clones. The two parental species had higher $\mathrm{N}$ contents than the hybrid clones. FBP had an extremely low nitrogen content of around $0.2 \% \mathrm{~N}$.

\section{Stilbene Content}

FJ had a higher stilbene content compared to the two $F$. xbohemica clones measured (Figure 4). Stilbene content was not affected by the soil $\mathrm{N}$ levels. However, the increase in the belowground biomass at the higher soil $\mathrm{N}$ level also brought about an increase in stilbene production (i.e., the amount of stilbenes in the belowground 
Table 1 Plant characteristics measured and tested in 2006 and 2007.

\begin{tabular}{|c|c|c|c|c|c|c|c|c|c|c|c|c|c|c|c|}
\hline \multicolumn{16}{|c|}{ Experimental factors and their effect on plant characteristics - significance levels } \\
\hline \multirow[t]{2}{*}{ Plant characteristics } & & \multicolumn{14}{|c|}{ Significance of factors and their interactions } \\
\hline & year & A & B & C & D & $A * B$ & $A^{*} \mathrm{C}$ & $A * D$ & $\mathrm{~B}^{*} \mathrm{C}$ & $B * D$ & $C * D$ & $A * B * C$ & $A * C * D$ & $B * C * D$ & $A * B * C * D$ \\
\hline Aboveground & & CLONE & INOC & $\mathrm{N}$ & LF DMG & & & & & & & & & & \\
\hline Plant d.m. (g) & 06,07 & 0.001 & NS & 0.001 & NS & NS & NS & NS & NS & NS & NS & NS & NS & NS & NS \\
\hline Plant height $(\mathrm{cm})$ & 06,07 & 0.001 & NS & 0.001 & NS & NS & NS & NS & NS & NS & NS & NS & NS & NS & NS \\
\hline Stem no & 06,07 & 0.001 & NS & 0.001 & NS & NS & NS & NS & NS & NS & NS & NS & 0.05 & NS & NS \\
\hline Branch no & 06,07 & 0.001 & NS & 0.001 & NS & NS & 0.001 & NS & NS & NS & 0.05 & NS & NS & NS & NS \\
\hline Branch total length $(\mathrm{cm})$ & 2006 & $x$ & $x$ & $x$ & $x$ & $x$ & $x$ & $x$ & $x$ & $x$ & $x$ & $x$ & $x$ & $x$ & $x$ \\
\hline Leaf no & 06,07 & 0.001 & NS & 0.001 & NS & NS & NS & NS & NS & NS & 0.01 & NS & NS & NS & NS \\
\hline Stem water content (\%) & 06,07 & 0.001 & NS & NS & NS & NS & NS & NS & NS & 0.05 & NS & NS & NS & NS & NS \\
\hline Leaf water content (\%) & 06,07 & 0.001 & NS & 0.001 & 0.05 & NS & NS & NS & NS & NS & 0.05 & NS & NS & NS & NS \\
\hline Leaf area $(\mathrm{cm} 2)$ & 06,07 & 0.001 & NS & 0.001 & NS & NS & NS & NS & NS & NS & NS & NS & NS & NS & NS \\
\hline $\mathrm{SLA}(\mathrm{cm} 2 / \mathrm{g})$ & 06,07 & NS & NS & 0.01 & NS & NS & NS & NS & NS & NS & NS & NS & NS & NS & NS \\
\hline \multicolumn{16}{|l|}{ Belowground } \\
\hline Root and rhizome d.m. (g) & 2007 & 0.001 & NS & 0.001 & 0.05 & NS & 0.01 & 0.01 & NS & NS & NS & NS & NS & NS & NS \\
\hline $\mathrm{N}(\%)$ & 2007 & 0.001 & 0.001 & 0.001 & 0.001 & 0.001 & 0.001 & 0.001 & NS & NS & NS & 0.05 & NS & NS & NS \\
\hline C (\%) & 2007 & NS & NS & NS & NS & NS & NS & NS & NS & NS & NS & NS & NS & NS & NS \\
\hline Resveratrol (mass \%) & 2007 & 0.001 & NS & NS & NS & NS & NS & NS & NS & NS & NS & NS & NS & NS & $x$ \\
\hline Piceid (mass \%) & 2007 & 0.001 & NS & NS & NS & NS & NS & NS & NS & NS & NS & NS & NS & NS & $x$ \\
\hline Stilbenes (mass \%) & 2007 & 0.001 & NS & NS & NS & NS & NS & NS & NS & NS & NS & NS & NS & NS & $x$ \\
\hline Emodin (mass \%) & 2007 & 0.001 & NS & 0.01 & NS & NS & NS & NS & NS & NS & NS & 0.05 & 0.05 & NS & $x$ \\
\hline Infection rate M (\%) & 2007 & 0.001 & $x$ & NS & 0.05 & $x$ & NS & 0.01 & $x$ & $x$ & NS & $x$ & NS & $x$ & $x$ \\
\hline Infection rate $\mathrm{F}(\%)$ & 2007 & 0.001 & $x$ & NS & 0.05 & $x$ & NS & NS & $x$ & $x$ & NS & $x$ & NS & $x$ & $x$ \\
\hline
\end{tabular}

Results of four-way ANOVA with the following factors: CLONE = knotweed clone; INOC = mycorrhizal inoculation; $\mathrm{N}=$ nitrogen level; LF DMG = leaf damage. Shown for data from 2007.

$\mathrm{x}=$ non-tested, NS = non-significant

biomass of one plant). FBM had the highest stilbene production (Figure 5). The biomass increase as a result of $\mathrm{N}$ fertilisation did not restrict the production of stilbenes at the $\mathrm{N}$ levels used in our experiment.

\section{Emodin content}

Figure 6 and Table 1 indicate that nitrogen had a positive effect on the emodin content in the belowground biomass of the knotweed. However, the increase of emodin content at higher soil nitrogen was only significant in FBM. The observed differences in emodin content of the individual clones were significant only at the lower soil $\mathrm{N}$ level, at which $\mathrm{FJ}$ produced the highest amount of emodin and FBM produced the lowest amount of emodin.

\section{Effect of mycorrhizal inoculation}

Mycorrhizal inoculation significantly lowered the $\mathrm{N}$ content in the belowground biomass of all knotweed clones with the exception of FBP. This effect was observed to various degrees within the different clones (see the significant interaction between mycorrhizal inoculation, clone and nitrogen level - Table 1), most likely as a result of the competition the microbial community brought into the system with the inoculum. Figure 7 gives about a summary of the effect of mycorrhizal inoculation on the $\mathrm{N}$ content with different combinations of clones and soil nitrogen level. Mycorrhizal inoculation had no effect on the production and the concentration of resveratrol, stilbenes and emodin.

\section{Effect of leaf damage}

The leaf damage negatively affected leaf water content, mycorrhizal colonisation and belowground biomass (Table 1). However, leaf damage had no effect on aboveground biomass, leaf area and SLA. The effect of leaf damage on the $\mathrm{N}$ content was more complicated (see Table 1, significant interactions). Leaf damage increased the $\mathrm{N}$ content in FBP at both soil $\mathrm{N}$ levels and in FBM at the higher soil $\mathrm{N}$ level and decreased the $\mathrm{N}$ content in FJ at the lower soil $\mathrm{N}$ level (Figure 8). Leaf damage had no effect on the $\mathrm{N}$ content in the belowground biomass of the knotweed in the inoculated variants.

Even though the effect of leaf damage on resveratrol and emodin content was not significant at $\mathrm{P}=0.05$ (Table 1), leaf damage significantly increased the resveratrol (from $0.027 \%$ to $0.035 \%$ ) and emodin (from $0.052 \%$ 

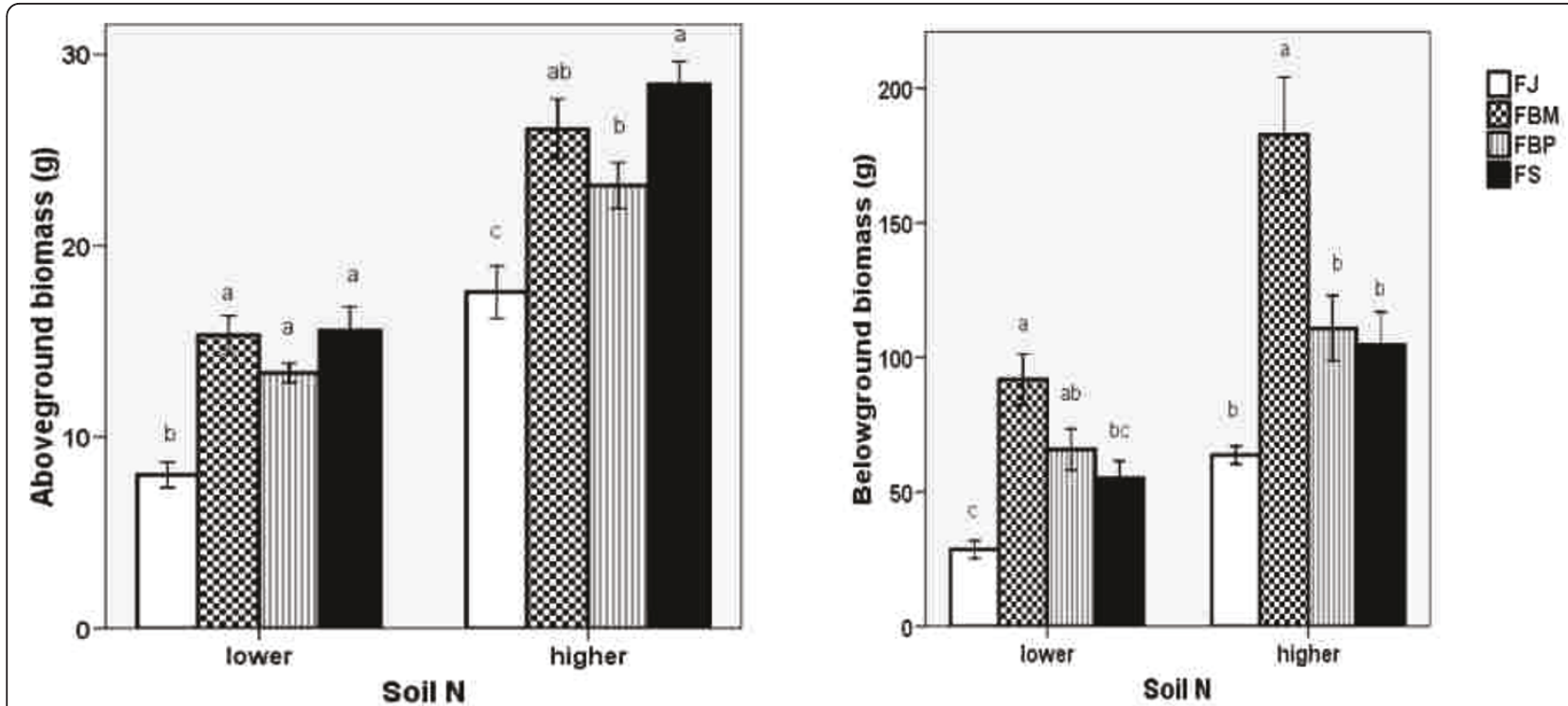

Figure 1 Above- and belowground biomass of knotweed. The above- (left) and belowground (right) biomasses ( \pm S.E) of the control plants of the four knotweed clones at the two soil N levels in 2007. FJ = Fallopia japonica, FBM = Fallopia xbohemica from Mošnov, FBP = Fallopia xbohemica from Průhonice, FS = Fallopia sachalinensis. For both soil N levels, the same letters indicate non-significant differences, $\mathrm{n}=10$.

to $0.062 \%$ ) content in belowground biomass of the noninoculated knotweed plants. Leaf damage had no effect on stilbene content but enhanced piceid content in the inoculated F. japonica (from $0.93 \%$ to $1.13 \%$ ). The leaf damage significantly lowered the intensity of mycorrhizal colonisation (both $\mathrm{F}$ and $\mathrm{M}$ - Table 1 ). $\mathrm{M}$ value decreased from $1.7 \%$ to $0.6 \%$ in FJ in response to leaf damage.

For more results see Additional file 1.

\section{Discussion}

Even though resveratrol is produced commercially from the Japanese knotweed in Asia, there is little knowledge concerning resveratrol and piceid contents of knotweed clones within the scientific literature. The lack of information may be due to the various efficiencies of the variety of extraction agents used or due to the measurement of the extract rather than the whole plant. We measured the stilbene yields of these plants under specific conditions designed to increase stilbene production by the knotweed. In addition, we determined the most efficient clone for the production of resveratrol and piceid.

Seasonal variability in the resveratrol and piceid contents Although it may be more economical to process the aboveground biomass rather than the rhizomes and roots, belowground biomass has a much higher content of stilbenes and emodin. Additionally, we found (unpublished data) that stilbene content in rhizomes peaked at the end of the growing season. Supposed that there is transport of these substances to the shoots in the spring, a seasonal variation may be then expected. A pronounced seasonal variation in resveratrol and piceid contents occurred in the aboveground biomass of the $F$. japonica at the beginning of its growth cycle (Figure 9). Knotweed is known for its fast growth rate in the spring and can produce up to $100 \mathrm{~mm}$ a day. Thus the

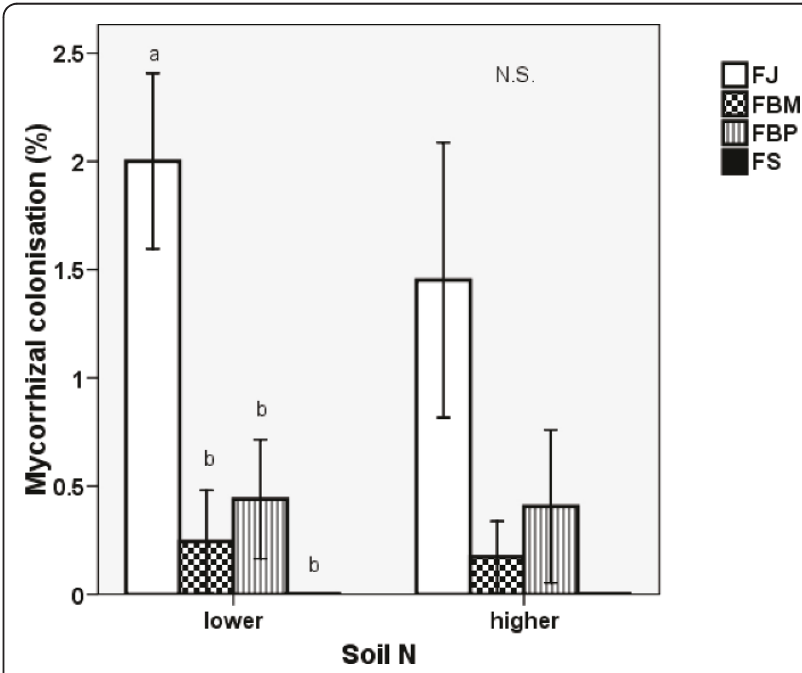

Figure 2 Mycorrhizal colonisation of knotweed. Mycorrhizal colonisation $\mathrm{M}( \pm$ S.E) in the inoculated plants of the four clones not exposed to leaf damage at the two soil $\mathrm{N}$ levels in 2007. FJ = Fallopia japonica, FBM = Fallopia $\times$ bohemica from Mošnov, FBP = Fallopia xbohemica from Průhonice, FS = Fallopia sachalinensis. For both soil $\mathrm{N}$ levels, the same letters indicate non-significant (NS) differences, $n=6$. 


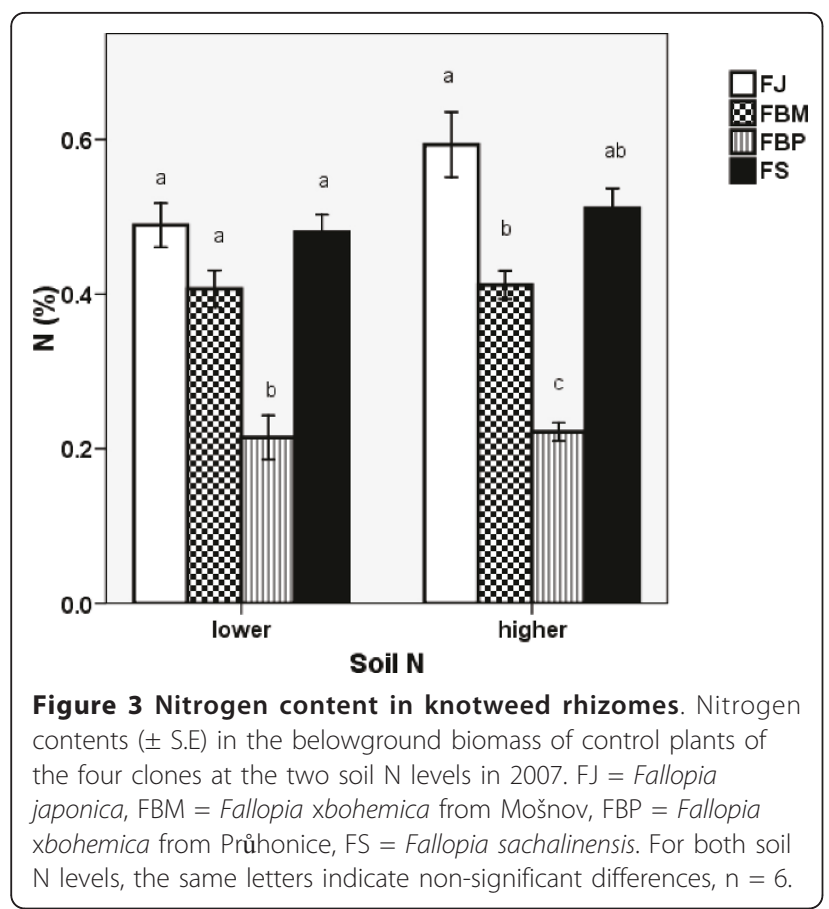

transport of substances from the rhizomes to the shoots results in a dillution in the total biomass pool. Both resveratrol and piceid possess antifungal activities and are present in high concentrations in the rhizomes $(0.04 \%$ and $1 \%$, resp.); when transported into shoots, they help to protect the fresh tissues from pathogens. In the foliage, the concentration of resveratrol gradually

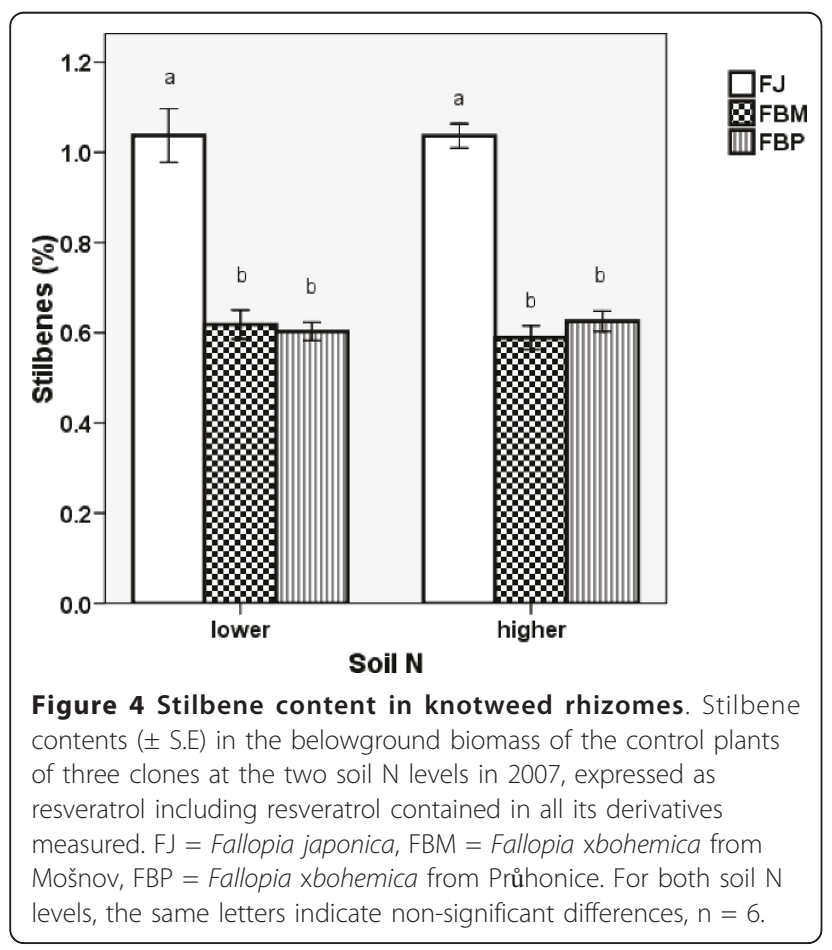

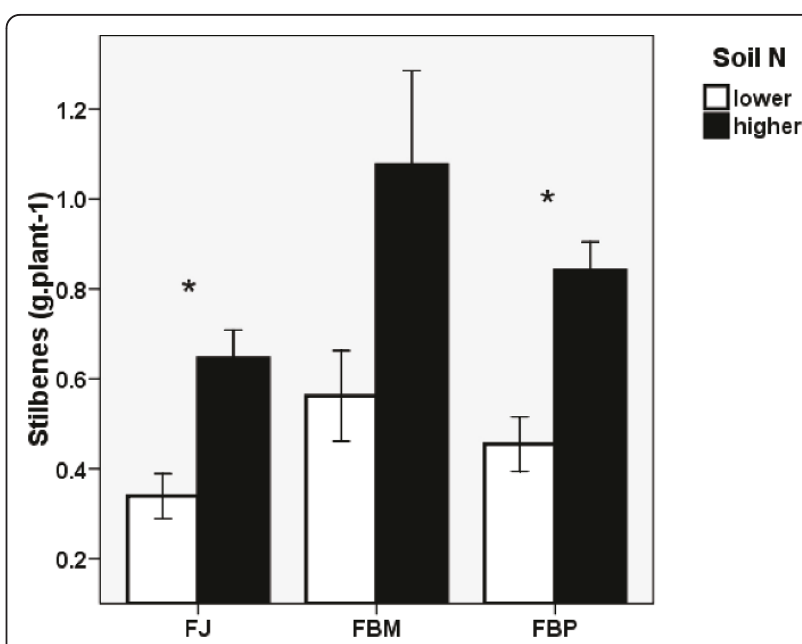

Figure 5 Nitrogen effect on stilbene production in knotweed. Effect of soil $\mathrm{N}$ level on the production of stilbenes per plant $( \pm$ S.E) in the belowground biomass of the control plants of three clones in 2007. FJ = Fallopia japonica, FBM = Fallopia $x$ bohemica from Mošnov, FBP = Fallopia $x$ bohemica from Průhonice. Asterisks indicate significant differences, $\mathrm{n}=6$.

increased up to $0.005 \%$. The concentration of piceid in the aboveground biomass showed high initial values that were followed by a significnat decrease before the full development of the shoots, and a subsequent increase up to $0.04 \%$. It is reasonable to assume that the transition between resveratrol (an aglycon) and piceid (a glucoside) depends on the amount of available glucose produced during photosynthesis.

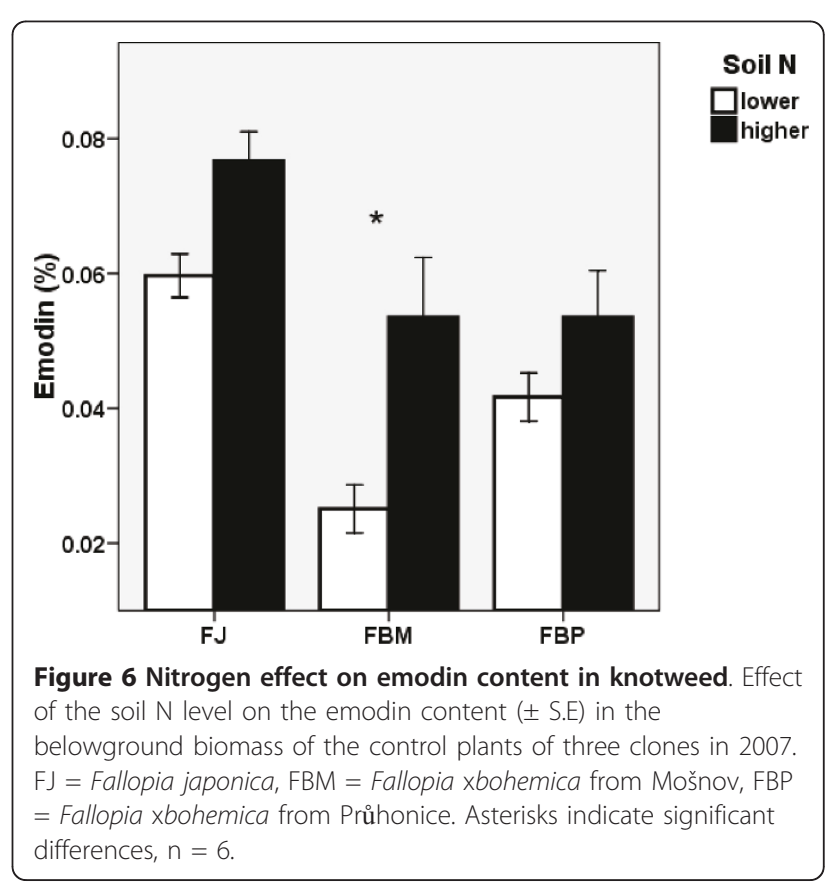




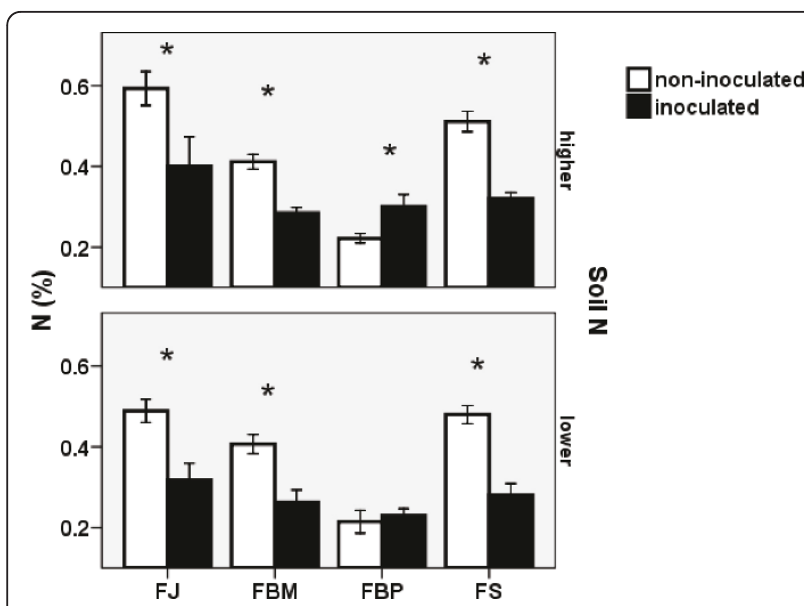

Figure 7 Effect of mycorrhizal inoculation on nitrogen content in knotweed rhizomes. Effect of mycorrhizal inoculation on the $\mathrm{N}$ content ( \pm S.E) in the belowground biomass of four clones at the higher (top) and lower (bottom) soil N levels. Only plants without exposure to leaf damage in 2007 are shown. FJ = Fallopia japonica, $\mathrm{FBM}=$ Fallopia $x$ bohemica from Mošnov, FBP = Fallopia $x$ bohemica from Průhonice, FS = Fallopia sachalinensis. Asterisks indicate significant differences, $\mathrm{n}=6$.

Interaction of leaf damage, mycorrhizal colonisation and piceid in $F$. japonica

Hartley and Firn [42] found increased levels of phenolics in damaged birch leaves. Similarly, increased concentrations of some phenolics including resveratrol in wounded spruce trees have been detected [43]. In our experiment, leaf damage elicited a positive effect on the piceid content in F. japonica, which is in line with these

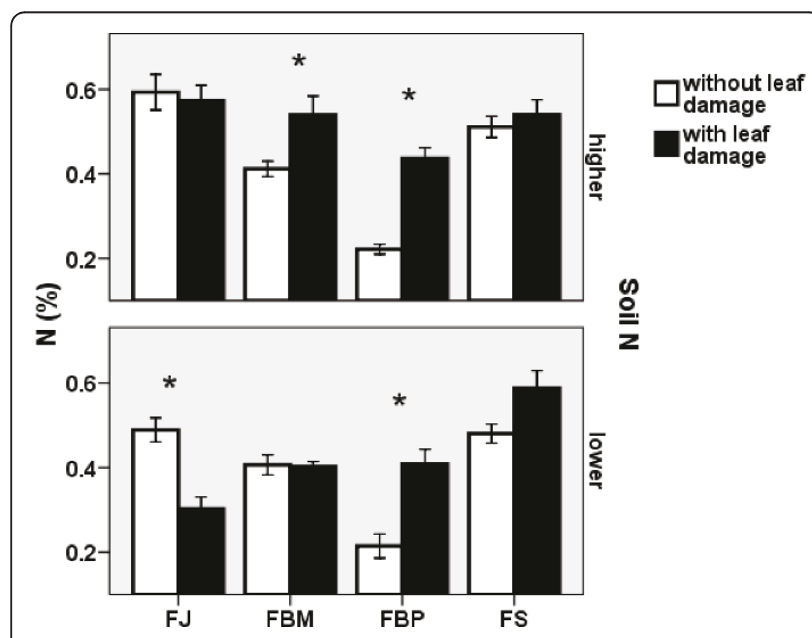

Figure 8 Effect of leaf damage on nitrogen content in knotweed rhizomes. Effect of leaf damage on the $\mathrm{N}$ content $( \pm \mathrm{S}$. E) in the belowground biomass of four clones at the higher (top) and lower (bottom) soil N levels. Only non-inoculated plants in 2007 are shown. FJ = Fallopia japonica, FBM = Fallopia $\times$ bohemica from Mošnov, FBP = Fallopia $\times$ bohemica from Průhonice, FS = Fallopia sachalinensis. Asterisks indicate significant differences, $n=6$.

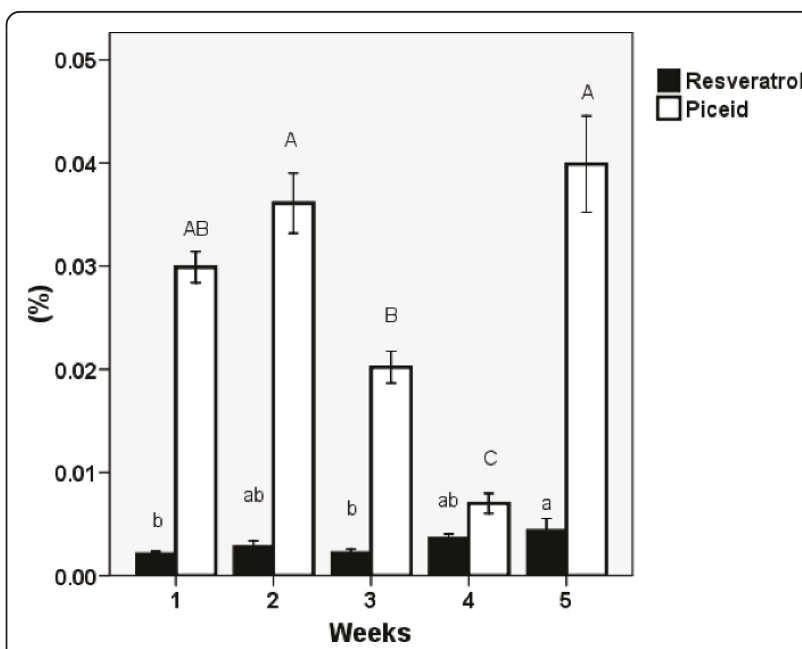

Figure 9 Seasonal variation of stilbene content in knotweed leaves. Seasonal variation in the content of resveratrol and piceid $( \pm$ S.E) in overall foliage per stem from the semi-natural population of F. japonica, from April 27 (plants ca $1 \mathrm{~m}$ high) to May 24 (fully grown plants), 2007. The same letters indicate non-significant differences in resveratrol (lower case) and piceid (upper case) contents, $\mathrm{n}=10$.

studies. F. japonica was most substantially affected by leaf damage out of the clones, most likely because it had the highest content of resveratrol derivatives, the majority of which was piceid (resveratrol-glucoside). Piceid may be viewed as a source from which resveratrol may be generated and has been shown to exert fungistatic effects; resveratrol itself was present in knotweed at very low amounts.

The most interesting findings pertain to the relationship between piceid, leaf damage and the intensity of mycorrhizal colonisation. In inoculated $F$. japonica, leaf damage increased piceid content, decreased the intensity of mycorrhizal colonisation and weakened the relationship between piceid and the intensity of mycorrhizal colonisation, which was significant and positive in plants not exposed to leaf damage. In plants exposed to leaf damage, no correlation was found between the intensity of mycorrhizal colonisation and piceid content in the belowground biomass of F. japonica because leaf damage increased its piceid content. However, there was a significant correlation in the undamaged plants. Figure 10 summarises these results, which suggest that in the Japanese knotweed, leaf damage stimulates piceid production to a greater extent than colonisation by mycorrhizal fungi. Leaf damage may even control the intensity of knotweed mycorrhizal colonisation, presumably because of the increased production of piceid.

Despite the fact that the mycorrhizal colonisation of the knotweed roots was low (2\%), a significant effect of mycorrhizae on the piceid levels in plants not exposed 


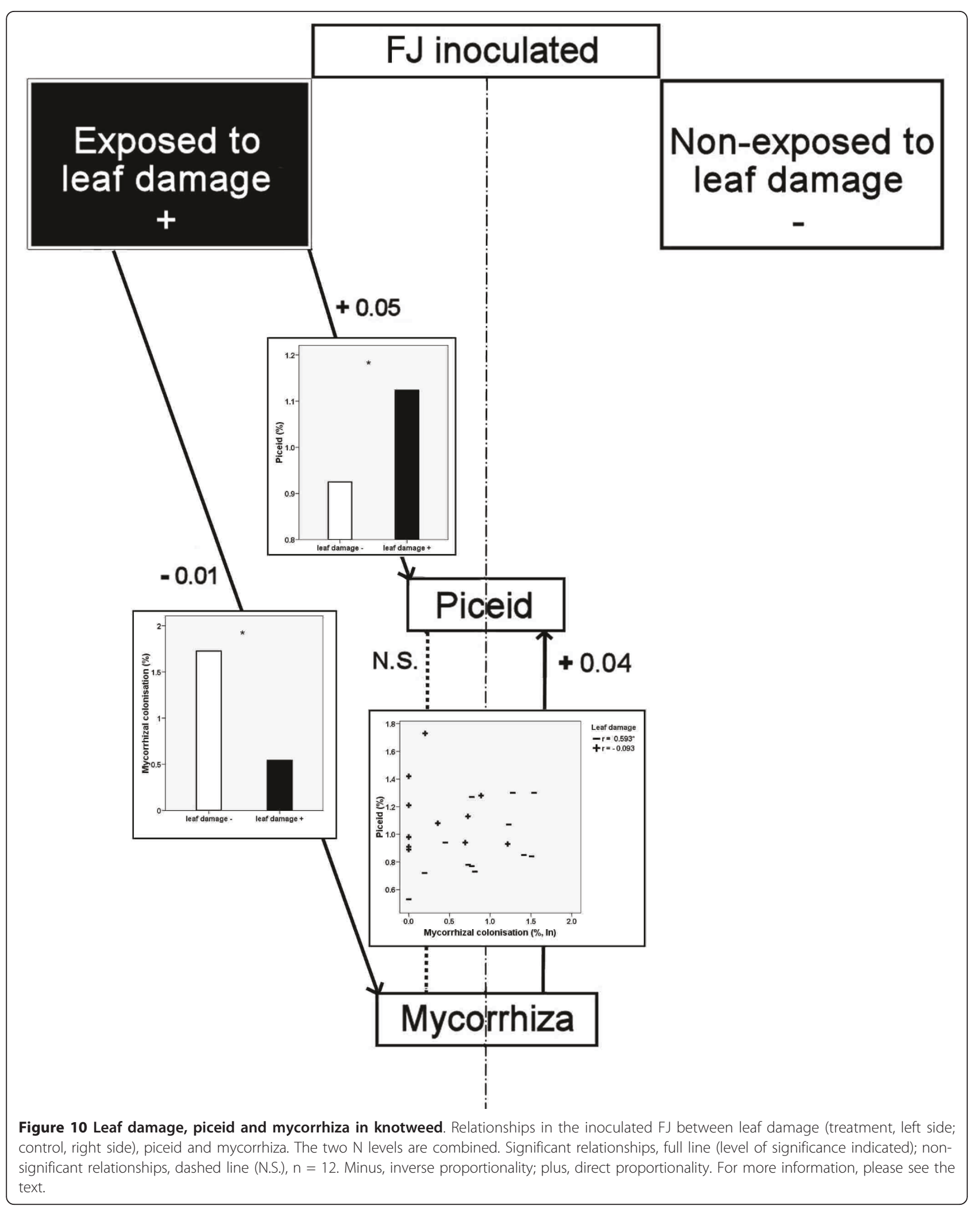


to leaf damage was still observed. Recent research on mycorrhiza has devoted more attention to the effects of low levels of colonisation by mycorrhizal fungi on their plant hosts $[44,45]$. Knotweeds are non-obligatelymycorrhizal plants and maintain low colonisation levels when they are grown in monocultures. However, when grown together with a typical mycorrhizal plant, such as leguminous melilot, they can be colonised up to $60 \%$ [8]. Our findings may be a small contribution to this discussion which touches upon new paradigms in mycorrhizal science.

Piceid is at least as effective in the prevention of fungal penetration into leaves as resveratrol. It was found that sorghum seedlings infected with the anthracnose pathogen Colletotrichum sublineolum accumulated trans-piceid as the major stilbene metabolite, along with an unknown resveratrol derivative [46]. In vitro experiments [47] revealed that piceid and resveratrol had an inhibitory effect on the germination of the phytopathogenic fungus Venturia inaequalis and its penetration through the cuticular membrane, which improved the resistance of plant leaves. It has been reported that resveratrol can be transformed into piceid by Bacillus cereus [48]. This evidence suggests that these two closely related substances have similar antifungal effects and can create an efficient barrier against the penetration of pathogenic fungi. In the sorghum cultivars [46], piceid was induced 48 hours after mycorrhizal inoculation. This result agrees with our finding that the exposure of knotweed leaves to leaf damage, as well as mycorrhizal colonisation of the knotweed roots, increased the piceid concentration in the belowground biomass. We hypothesise that damage to the leaves increased the piceid level, which then restricted the mycorrhizal colonisation of the roots.

\section{Piceid/N ratio}

As shown in Table 1, $\mathrm{N}$ content in rhizomes was strongly affected by all the factors tested in the pot experiment. We found an interesting relationship between $\mathrm{N}$ and piceid contents in rhizomes of knotweed clones. Piceid is a transient molecule and its content increases when there are enough energy-rich glucosides available; resveratrol is a suitable receptor on which glucosides are bound. According to the protein competition model of phenolic allocation [14], plants use photosynthetic carbon products (phenylalanine) predominantly for the synthesis of secondary metabolites, such as phenolics, alkaloids, stilbenes and/or lignin when the nitrogen availability is low and for the synthesis of proteins at higher $\mathrm{N}$ concentrations. A negative correlation between leaf phenolic and nitrogen contents has been reported [49]; however, we did not find a relationship between the nitrogen and piceid contents in the belowground biomass of the individual knotweed clones tested. Figure 11 shows the consistent differences between the piceid content of the clones related to the nitrogen content. The highest concentrations of piceid were measured in the belowground biomass of FJ. The two hybrid clones, FBM and FBP, had about the same piceid content but differed in their $\mathrm{N}$ content (Figure 11a). The exposure of these clones to leaf damage eliminated this difference by increasing the very low $\mathrm{N}$ content in FBP. The positive effect of both leaf damage and mycorrhizal inoculation on the ratio of piceid to $\mathrm{N}$ content is a novel finding.

In another experiment with $F$. xbohemica [8] we found that the piceid/N ratio significantly decreased (from 1.7 to 1.2) because of the presence of melilot, which enriched the system with nitrogen fixed by its rhizobia. In this experiment, the piceid/ $\mathrm{N}$ ratio was significantly increased by leaf damage (Figure 11b) in FJ (from 2 to 3 ) and by mycorrhizal inoculation (Figure 11c) both in FJ (from 2 to 3 ) and FBM (from 1 to 1.7). Two things that likely contributed to the increased piceid/N ratio were the net increase of piceid in FJ subjected to leaf damage, resulting from a defence response, and a decrease of nitrogen in FJ and FBM, resulting from mycorrhizal inoculation. This decrease was likely caused by competition with soil microorganisms for nitrogen.

\section{Conclusions}

Significant production of stilbenes and emodin was found in two widely spread knotweeds, F. japonica and $F$. xbohemica, which were cultivated in pots in the ash substrate. The content of some target compounds in the plant tissue can be significantly altered by these means:

1) manipulation of the nitrogen content in the substrate - the increase in biomass as a result of the $\mathrm{N}$ fertilisation did not restrict the production of stilbenes at the $\mathrm{N}$ levels used in our experiment;

2) imposing stress on plants - leaf damage increased the resveratrol and emodin contents in the belowground biomass of the non-inoculated knotweed plants;

3) inoculation with mycorrhizal fungi - mycorrhizal fungi elicited an increase in the piceid (resveratrol-glucoside) content in the belowground biomass of $F$. japonica, but only in the absence of leaf damage.

4) selection of the appropriate plant clone - the production of secondary compounds differed among the plant clones tested. Despite the higher concentration of these substances in $F$. japonica, their total production is higher in the two clones of $F$. xbohemica, because of their higher biomass produced per plant.

Both Fallopia japonica and the two clones of F. xbohemica (FBM and FBP) are promising sources of resveratrol and piceid, which possess the potential to protect and improve human health. 


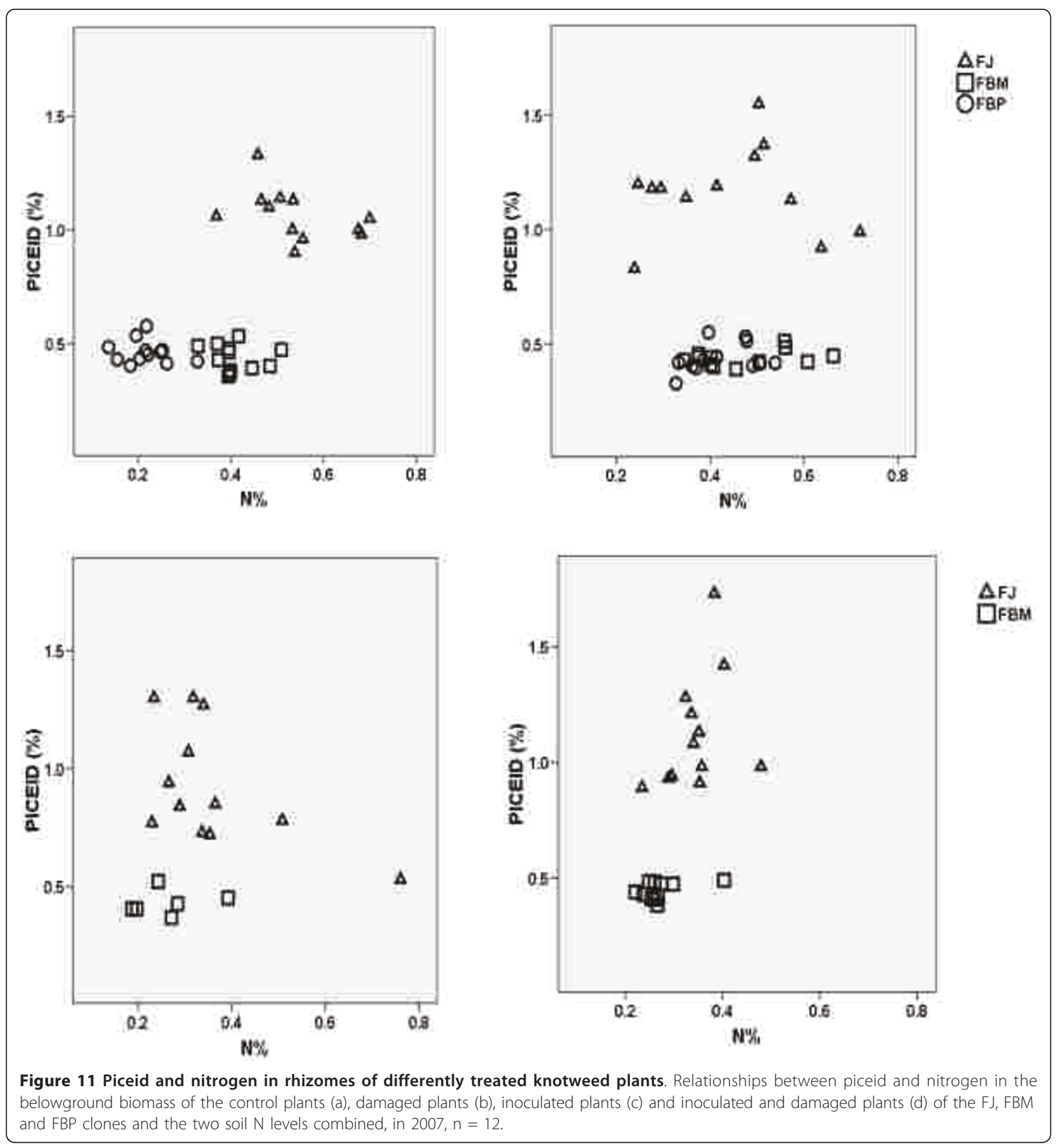

\section{Methods}

\section{Plant material}

Prior to the pot experiment, a survey was made concerning the resveratrol and piceid contents using a collection of genetically defined clones with known ploidy levels, in the experimental garden of the Institute of Botany, Czech Academy of Science [50]. Rhizomes were sampled from 20 different clones including Fallopia japonica, F. sachalinensis and F. xbohemica. F. japonica occurs only as a singular, octoploid clone, whereas $F$. sachalinensis and F. xbohemica were found as tetraploid, hexaploid and octoploid clones. As there was no relationship between the ploidy level and the content of either resveratrol and/or piceid in the knotweed rhizomes, the choice of which hybrid clones to use in our pot experiment (FBM and FBP) was made by using the 
following criteria: (1) resveratrol and piceid content, (2) environmental safety (some of these clones were appointed as "extremely dangerous" and it was recommended that we would avoid those indicated as dangerous, and implement only clones which are safe enough to work within the pot experiment - traditionally known as non-spreading, i.e., occupying the same space in the long-term and forming no viable seeds; B. Mandák, personal communication), (3) reasonable growth (stable, persistent and vital populations) and (4) rhizome availability (sufficient amounts/proportion of young rhizomes; old populations were avoided). Out of the parental clones, F. japonica var. japonica (octoploid) was an obvious choice as the other clone of $F$. japonica, F. japonica var. compacta does not grow well. F. sachalinensis (tetraploid) was sampled from a population closest to the location where the hybrid was first described.

The pot experiment started in September 2005 when the rhizome segments of the knotweed were planted. They were ca. four cm long; we rid the plant rhizomes of all roots and immersed them for 15 min. into a $20 \%$ solution of Savo (sodium hypochlorite) for sterilisation of their surface. The rhizomes were sampled from four clones of Fallopia, namely F. sachalinensis (F. Schmidt Petrop.) Ronse Decr. ( $n=44$; genome size: $2 \mathrm{C}$-values $\mathrm{DNA}=4.345 \mathrm{pg}$; FS) from a wild stand in Průhonice on the banks of the Botič stream, F. xbohemica (Chrtek et Chrtková) J. P. Bailey ( $\mathrm{n}=66$; genome size: $2 \mathrm{C}$-values DNA $=6.918$ pg; FBP) from a wild stand alongside the Botič stream, Průhonice, $R$ xbohemica ( $\mathrm{n}=66$; genome size: $2 \mathrm{C}$-values DNA $=6.945 \mathrm{pg} ; \mathrm{FBM}$ ) from a field culture in Mošnov and F. japonica (Houtt.) Ronse Decr. (n = 88; genome size: $2 \mathrm{C}$-values DNA = $9.541 \mathrm{pg}$; FJ) from a semi-natural population in an abandoned garden in Prague. The seasonal variation in the resveratrol and piceid content in the shoots was estimated in 2007. Genome size was estimated by the same method as described by [50]

\section{Experimental design}

The pot volume was $10 \mathrm{l}$, with the bottoms covered by a sterile textile to keep the material inside; a total of 320 pots were used. Two thirds of the volume was filled with a 9:1 v/v mixture of ash from a granulating furnace (for chemical composition see Table 2) delivered directly from its source, the power station in Božkov near Plzeň, and sterile (25 kGrey gamma-irradiated) low-N bark compost $(0.6-0.7 \% \mathrm{~N}, \mathrm{pH} 5.5)$. One half of the pots was inoculated with a mixed inoculum of 3 isolates of arbuscular mycorrhizal (AM) fungi: Glomus mossae BEG95, G. claroideum BEG96 and G. intraradices BEG140 (all originated from man-made sites). The inoculum was produced on roots of maize grown in a mixture of zeolite and river sand $(1: 1 \mathrm{v} / \mathrm{v})$ in the greenhouse for 4
Table 2 Elemental content of the alcaline $\left(\mathrm{pH}\left(\mathrm{H}_{2} \mathrm{O}\right)=\right.$ $8.00 ; \mathrm{pH}(\mathrm{KCl})=7.94)$ ash used as a substrate in the pot experiment.

\begin{tabular}{cc}
\hline \multicolumn{2}{c}{ Chemical composition of the pot substrate } \\
\hline Element & Content (ppm) \\
\hline${\mathrm{C}-\mathrm{CO}_{3}}$ & 1480 \\
\hline $\mathrm{P}$ & 102 \\
\hline $\mathrm{Ca}$ & 32842 \\
\hline $\mathrm{Mg}$ & 1110 \\
\hline $\mathrm{K}$ & 789 \\
\hline $\mathrm{Ag}$ & $<5.6$ \\
\hline $\mathrm{As}$ & 67 \\
\hline $\mathrm{Ba}$ & 730 \\
\hline $\mathrm{Cd}$ & $<1.2$ \\
\hline $\mathrm{Co}$ & 24 \\
\hline $\mathrm{Cr}$ & 46 \\
\hline $\mathrm{Cu}$ & 240 \\
\hline $\mathrm{Hg}$ & 0.9 \\
\hline $\mathrm{Ni}$ & 35 \\
\hline $\mathrm{Pb}$ & 5.8 \\
\hline $\mathrm{Zn}$ & 52 \\
\hline
\end{tabular}

Majority of its particles fell in the category $10-50 \mu \mathrm{m}(50 \%)$, followed by 100 $2000 \mu \mathrm{m}(40 \%)$.

months. Each inoculated pot received $100 \mathrm{ml}$ of inoculum of AM fungi, consisting of equal volumes of spores, colonized root pieces and fragments of extraradical mycelium of each fungal isolate. The second half of the pots (non-inoculated control treatment) was supplied with the same quantity of heat-sterilised inoculum plus $100 \mathrm{ml}$ of inoculum-filtrate to obtain a similar quantity of organic matter and microbial conditions (except viable AM fungi) in all treatments. The pots were filled to the rim with the same substrate and the surface was covered with $1 \mathrm{~L}$ of the same sterilised bark compost which was used in the mixture with ash. One hundred $\mathrm{ml}$ of filtrate from the bark compost containing native microflora (but not AM fungi) was added to all treatments. The filtrates from the inoculum and from the bark compost were prepared by shaking $100 \mathrm{~g}$ of inoculum or compost, respectively, with $1 \mathrm{~L}$ of deionized water for $30 \mathrm{~min}$ and filtered twice through filter paper with a pore size of $10 \mu \mathrm{m}$. The pots were then placed in a greenhouse for the winter but kept outside on the greenhouse tables during the growing season. A dripirrigation system was applied (Rainbird, USA) with a separate tube for each pot, which prevented the sun from burning the wet leaves and cross-contamination between inoculated and non-inoculated substrates.

Equal amounts of phosphorus $(90 \mathrm{mg} /$ pot, equivalent of $20 \mathrm{~kg} / \mathrm{ha}$ ), in the form of $\mathrm{KH}_{2} \mathrm{PO}_{4}$, were applied to the pots at the beginning of the experiment and again 
in September 2006. All pots (area $452 \mathrm{~cm}^{2}$ ) were treated with $20 \mathrm{~kg} / \mathrm{ha}$ of $\mathrm{N}$ in the form of carbamide $\left(\mathrm{NH}_{2}-\mathrm{CO}\right.$ $\mathrm{NH}_{2}$ ), which contained $46 \% \mathrm{~N}$, in June 2006 , and only the high- $\mathrm{N}$ plants received four additional $\mathrm{N}$ doses from August to September in 2006 and 2007. In the summer of 2007, when the leaves were fully developed, all of them were gently punctured with a sterilised stainless steel pet brush with a wire diameter of $0.25 \mathrm{~mm}$ and a density of $1242 \mathrm{pcs} / \mathrm{dm}^{2}$. The area of the brush was 75 $\times 28 \mathrm{~mm}$; the leaves had a strip of $28 \mathrm{~mm}$ punctured across their width.

There were 10 replicates for each clone $\times \mathrm{N} \times$ mycorrhizal colonization $\times$ leaf damage combination, the pots were fully randomized.

\section{Plant growth analysis}

The process of translocation of nutrients as well as secondary compounds into the underground organs ceases simultaneously with plant growth decline at the end of the growth season, typically in October. In the pots, the plants were harvested in October 2006 for aboveground biomass and in October 2007 for both above- and belowground biomass. On the day of sampling, the shoots were cut, and the following plant growth characteristics of each ramet were recorded: number of leaves, the leaf area $\left(\mathrm{cm}^{2}\right)$, the fresh and dry weight of leaves and stems $(\mathrm{g})$. Leaf area was measured using LI-COR LI-3000 planimeter.

Using these data, the aboveground biomass, leaf and stem water content (100*(fresh weight - dry)/fresh weight) and specific leaf area (SLA = leaf area/leaf dry wt; $\mathrm{cm}^{2} \cdot \mathrm{g}^{-1}$ ) to assess leaf thickness were calculated. The belowground biomass was measured after washing and cleaning of the roots and rhizomes that were dried, weighed, ground and analysed for $\mathrm{C}, \mathrm{N}$ and organic substances.

To estimate seasonal variability of resveratrol and piceid contents, leaves were sampled at the beginning of the growth season, weekly from April 27 to May 24, dried, ground and analysed for organic substances.

\section{Mycorrhizal colonisation assessment}

The roots were washed from the soil on a sieve, cut into one to two $\mathrm{cm}$ segments and stained with $0.05 \%$ Trypan blue in lactoglycerol [51]. Mycorrhizal colonisation (arbuscules, vesicles and internal hyphae) was checked under a compound microscope (Olympus $B \times 41$ ) at $100 \times$ magnification. The frequency $(\mathrm{F})$ and intensity (M) of mycorrhizal colonisation of the roots were evaluated according to previously described methods [52].

\section{Chemical analyses}

Stilbenes, including resveratrol, piceatannol and resveratrol glucosides (piceid, resveratrolosid, astringins), were analysed as well as emodin. To determine the resveratrol content, it is important to measure not only the resveratrol content but also the content of the resveratrol glucosides. These are easily split into resveratrol and sugars, a process that will increase the measured resveratrol content. (A simple low-cost patented technological process for raising resveratrol content in knotweed includes fermentation for $24-96 \mathrm{~h}$ at $20-50^{\circ} \mathrm{C}$; see http:// en.cnki.com.cn/Article_en/CJFDTOTAL-

JXHG200805014.htm) Dry and finely (0.01 mm sieve) ground samples were extracted with $60 \%$ ethanol, as it was the most efficient extractant for both resvertrol and its glucosides. The extracts were analysed by validated HPLC-UV method. Instrument: Shimadzu LC2010C HT with UV detection $306 \mathrm{~nm}$; column: Phenomenex synergi Hydro-RP $80 \mathrm{~A}, 250 \times 4.6 \mathrm{~mm}, 4 \mu \mathrm{m}\left(30^{\circ} \mathrm{C}\right)$; flow rate: $1.5 \mathrm{ml} \cdot \mathrm{min}^{-1}$; mobile phases: A - $10 \mathrm{mM}$ ammonium acetate at $\mathrm{pH} 4.15$ using acetic acid, B acetonitrile, concentration gradient from $7 \%$ to $90 \%$. Standards: Piceid: 98\%, OSA: 59394; Resveratrol: 99\%, Sigma-Aldrich; Emodin: 98\%, OSA: 59395; Astringin: 99\%, Polyphenols; Piceatannol: 99\%, Sigma Aldrich. External standard method with calibration curve was used for quantification.

Nitrogen and carbon in rhizomes were measured in the Analytical Laboratory of the Botanical Institute, Czech Acad. Sci., Průhonice, as total elemental content after combustion in an oxygen atmosphere $(\mathrm{N}, \mathrm{C})$ in a CarloErba analyser. Macronutrients in the ash were measured according to [53] apart of phosphorus which was measured in bicarbonate extract at pH 8.5 [54]. Particle size analysis of the ash substrate was made in sedimentograph Analysette 20 by Fritsch. Analyses of heavy metals were bestowed by ash supplier Plzeňská teplárenská, a.s.

\section{Data analysis}

Data with normal distributions were tested by multi-way ANOVA and Tukey test. Other data were evaluated using nonparametric tests such as Kruskal-Wallis and Mann-Whitney. Correlation analysis used Pearson's coefficient $r$. The statistical program employed was SPSS 14.0. The significance level of $P=0.05$ was used if not otherwise indicated.

\section{Additional material}

Additional file 1: Supplementary data on pot experiment. This file contains more details on statistics (F-values and degrees of freedom) and several other plant characteristics, such as stem, branch and leaf numbers, leaf area, SLA, stem and leaf water contents and carbon content, reflecting the effects of experimental factors.

\section{Acknowledgements}

The authors acknowledge the support of B. Mandák for supplying us with valuable information and material from the knotweed clone collection, of M. Bartoš who supervised the organic chemical analyses, and of M. Janoušková, 
J. Rydlová and R. Sudová who advised on mycorrhizal issues. We are grateful to M. Albrechtová for the chemical analyses of nitrogen and carbon, to J. Kubovec who supplied the experimental plant material, and the staff of the experimental garden for their support with care of the experimental plants. AJE improved the language quality of the text. The authors greatly appreciate the help of two anonymous reviewers, of the BMC editors and J. Sadowsky who all much improved the final draft. This paper was funded by grant MIT CR, FT-TA3/008, MSMT/1M0571 and AVOZ60050516.

\section{Author details}

'Institute of Botany, Czech Academy of Science, Průhonice 1, 252 43, Czech Republic. ${ }^{2} V u ́ O S$, Rybitví 296, 53354 Rybitví, Czech Republic.

\section{Authors' contributions}

MK conceived the study, coordinated the experiments and drafted the manuscript. TF performed the statistical analyses, prepared the graphs and commented on the draft text. KB performed the mycorrhizal part of the study. HK participated substantially in the experimental work and in the communication between the group members. $\mathrm{ZN}$ performed the organic chemical analyses. MV designed the experiment and contributed to the written manuscript. All authors read and approved the final paper.

Received: 30 December 2010 Accepted: 30 May 2011

Published: 30 May 2011

\section{References}

1. Mandak B, Pysek P, Bimova K: History of the invasion and distribution of Reynoutria taxa in the Czech Republic: a hybrid spreading faster than its parents. Preslia 2004, 76:15-64.

2. Pysek P, Brock JH, Bimova K, Mandak B, Jarosik V, Koukolikova I, Pergl J, Stepanek J: Vegetative regeneration in invasive Reynoutria (Polygonaceae) taxa: The determinant of invasibility at the genotype level. American Journal of Botany 2003, 90(10):1487-1495.

3. Murrell C, Gerber E, Krebs C, Parepa M, Schaffner U, Bossdorf O: Invasive Knotweed Affects Native Plants through Allelopathy. American Journal of Botany 2011, 98(1):38-43.

4. Gerber E, Krebs C, Murrell C, Moretti M, Rocklin R, Schaffner U: Exotic invasive knotweeds (Fallopia spp.) negatively affect native plant and invertebrate assemblages in European riparian habitats. Biological Conservation 2008, 141(3):646-654.

5. Barták R, Konupková-Kalousová Š, Krupová B: Metodika likvidace invazních druhů kř́dlatek (Reynoutria spp.). Český Těšín 2010, 32.

6. Fan EG, Zhang K, Zhu MZ, Wang QA: Obtaining Resveratrol: from Chemical Synthesis to Biotechnological Production. Mini-Reviews in Organic Chemistry 2010, 7(4):272-281.

7. Strasil Z: Kř́dlatky (Knotweeds) (Reynoutria). In Energetic Plants. Edited by: Petřiková Vea. Profi Press: Praha; 2006:33-39.

8. Kovarova M, Bartunkova K, Frantik T, Koblihova H, Prchalova K, Vosatka M: Factors influencing the production of stilbenes by the knotweed, Reynoutria xbohemica. BMC Plant Biology 2010, 10:19.

9. Bimova K, Mandak B, Pysek P: Vegetative regeneration in invasive Reynoutria Polygonaceae): a comparative experimental study of four congeners. Plant Ecology 2003, 166:1-11.

10. Hirose T: Nitrogen Use Efficiency in Growth of Polygonum-Cuspidatum Sieb Et Zucc. Annals of Botany 1984, 54(5):695-704.

11. Hirose T, Kitajima K: Nitrogen Uptake and Plant-Growth.1. Effect of Nitrogen Removal on Growth of Polygonum-Cuspidatum. Annals of Botany 58(4):479-486.

12. Fuiyoshi M, Masuzawa T, Kagawa A, Nakatsubo T: Successional changes in mycorrhizal type in the pioneer plant communities of a subalpine volcanic desert on Mt. Fuji, Japan. Polar Biosci 2005, 18:60-72.

13. Bavaresco L, Pezzutto S, Ragga A, Ferrari F, Trevisan M: Effect of nitrogen supply on trans-resveratrol concentration in berries of Vitis vinifera L.cv. Cabernet Sauvignon. Vitis 2001, 40(4):229-230.

14. Jones CG, Hartley SE: A protein competition model of phenolic allocation. Oikos 1999, 86(1):27-44.

15. Muto A, Hori M, Sasaki Y, Saitoh A, Yasuda I, Maekawa T, Uchida T, Asakura K, Nakazato T, Kaneda T, Kizaki M, Ikeda Y, Yoshida T: Emodin has a cytotoxic activity against human multiple myeloma as a Janus-activated kinase 2 inhibitor. Mol Cancer Ther 2007, 6(3):987-94.
16. Fu ZY, Han JX, Huang HY: Effects of emodin on gene expression profile in small cell lung cancer NCI-H446 cells. Chinese Medical Journal 2007, 120(19):1710-1715.

17. Pecere T, Gazzola MV, Mucignat C, Parolin C, Dalla Vecchia F, Cavaggioni A, Basso G, Diaspro A, Salvato B, Carli M, Palu G: Aloe-emodin is a new type of anticancer agent with selective activity against neuroectodermal tumors. Cancer Research 2000, 60(11):2800-2804.

18. Lu YY, Zhang JL, Qian JM: The effect of emodin on VEGF receptors in human colon cancer cells. Cancer Biotherapy and Radiopharmaceuticals 2008, 23(2):222-228.

19. Shieh DE, Chen YY, Yen MH, Chiang LC, Lin CC: Emodin-induced apoptosis through p53-dependent pathway in human hepatoma cells. Life Sci 2004, 74(18):2279-90.

20. Docherty JJ, Fu MM, Tsai M: Resveratrol selectively inhibits Neisseria gonorrhoeae and Neisseria meningitidis. Journal of Antimicrobial Chemotherapy 2001, 47(2):243-244.

21. Chan MMY: Antimicrobial effect of resveratrol on dermatophytes and bacterial pathogens of the skin. Biochemical Pharmacology 2002, 63(2):99-104.

22. Jung HJ, Hwang IA, Sung WS, Kang H, Kang BS, Seu YB, Lee DG: Fungicidal effect of resveratrol on human infectious fungi. Archives of Pharmacal Research 2005, 28(5):557-560.

23. Schubert R, Fischer R, Hain R, Schreier PH, Bahnweg G, Ernst D, Sandermann $\mathrm{H}$ : An ozone-responsive region of the grapevine resveratrol synthase promoter differs from the basal pathogen-responsive sequence. Plant Molecular Biology 1997, 34(3):417-426.

24. Soleas GJ, Diamandis EP, Goldberg DM: Resveratrol: A molecule whose time has come? And gone? Clinical Biochemistry 1997, 30(2):91-113.

25. Ulrich S, Wolter F, Stein JM: Molecular mechanisms of the chemopreventive effects of resveratrol and its analogs in carcinogenesis. Molecular Nutrition \& Food Research 2005, 49(5):452-461.

26. Wolter F, Ulrich S, Stein J: Molecular mechanisms of the chemopreventive effects of resveratrol and its analogs in colorectal cancer: Key role of polyamines? Journal of Nutrition 2004, 134(12):3219-3222.

27. Sun WM, Wang W, Kim J, Keng P, Yang SM, Zhang HS, Liu CM, Okunieff $P$, Zhang LR: Anti-cancer effect of resveratrol is associated with induction of apoptosis via a mitochondrial pathway alignment. Oxygen Transport to Tissue Xxix 2008, 614:179-186.

28. El-Mowafy AM, Alkhalaf M: Resveratrol activates adenylyl-cyclase in human breast cancer cells: a novel, estrogen receptor-independent cytostatic mechanism. Carcinogenesis 2003, 24(5):869-873.

29. Kerem Z, Bilkis I, Flaishman MA, Sivan U: Antioxidant activity and inhibition of alpha-glucosidase by trans-resveratrol, piceid, and a novel trans-stilbene from the roots of Israeli Rumex bucephalophorus L. Journal of Agricultural and Food Chemistry 2006, 54(4):1243-1247.

30. Jeandet $P$, Bessis $R$, Maume BF, Meunier P, Peyron D, Trollat P: Effect of Enological Practices on the Resveratrol Isomer Content of Wine. Journal of Agricultural and Food Chemistry 1995, 43(2):316-319.

31. Langcake P, Mccarthy WV: Relationship of Resveratrol Production to Infection of Grapevine Leaves by Botrytis-Cinerea. Vitis 1979, 18(3):244-253.

32. Filip V, Plockova M, Smidrkal J, Spickova Z, Melzoch K, Schmidt S: Resveratrol and its antioxidant and antimicrobial effectiveness. Food Chemistry 2003, 83(4):585-593.

33. Bavaresco L, Vezzulli S, Battilani P, Giorni P, Pietri A, Bertuzzi T: Effect of ochratoxin A-producing Aspergilli on stilbenic phytoalexin synthesis in grapes. Journal of Agricultural and Food Chemistry 2003, 51(21):6151-6157.

34. Adrian $M$, Jeandet $P$, Veneau J, Weston LA, Bessis R: Biological activity of resveratrol, a stilbenic compound from grapevines, against Botrytis cinerea, the causal agent for gray mold. Journal of Chemical Ecology 1997, 23(7):1689-1702.

35. Harley JL, Harley EL: A Checklist of Mycorrhiza in the British FloraAddenda, Errata and Index. New Phytologist 1987, 107(4):741-749.

36. Gianinazzi S, Gollotte A, Binet MN, van Tuinen D, Redecker D, Wipf D: Agroecology: the key role of arbuscular mycorrhizas in ecosystem services. Mycorrhiza 2010, 20(8):519-530

37. Jain E, Bairoch A, Duvaud S, Phan I, Redaschi N, Suzek BE, Martin MJ, McGarvey P, Gasteiger E: Infrastructure for the life sciences: design and implementation of the UniProt website. Bmc Bioinformatics 2009, 10.

38. Xu W, Yu Y, Ding J, Hua Z, Wang Y: Characterization of a novel stilbene synthase promoter involved in pathogen- and stress-inducible 
expression from Chinese wild Vitis pseudoreticulata. Planta 2010, 231(2):475-87.

39. Grafi G, Chalifa-Caspi V, Nagar T, Plaschkes I, Barak S, Ransbotyn V: Plant response to stress meets dedifferentiation. Planta 2011, 233(3):433-8.

40. Dixon RA, Paiva NL: Stress-Induced Phenylpropanoid Metabolism. Plant Cell 1995, 7(7):1085-1097.

41. Nykanen $\mathrm{H}$, Koricheva J: Damage-induced changes in woody plants and their effects on insect herbivore performance: a meta-analysis. Oikos 2004, 104(2):247-268

42. Hartley SE, Firn RD: Phenolic Biosynthesis, Leaf Damage, and Insect Herbivory in Birch (Betula-Pendula). Journal of Chemical Ecology 1989, 15(1):275-283.

43. Evensen PC, Solheim H, Hoiland K, Stenersen J: Induced resistance of Norway spruce, variation of phenolic compounds and their effects on fungal pathogens. Forest Pathology 2000, 30(2):97-108.

44. Grace EJ, Cotsaftis O, Tester M, Smith FA, Smith SE: Arbuscular mycorrhizal inhibition of growth in barley cannot be attributed to extent of colonization, fungal phosphorus uptake or effects on expression of plant phosphate transporter genes. New Phytologist 2009, 181(4):938-949.

45. Smith FA, Grace EJ, Smith SE: More than a carbon economy: nutrient trade and ecological sustainability in facultative arbuscular mycorrhizal symbioses. New Phytol 2009, 182(2):347-58.

46. Yu CK Y, Shih CH, Chu IK, Lo C: Accumulation of trans-piceid in sorghum seedlings infected with Colletotrichum sublineolum. Phytochemistry 2008, 69(3):700-706.

47. Schulze K, Schreiber L, Szankowski I: Inhibiting effects of resveratrol and its glucoside piceid against Venturia inaequalis, the causal agent of apple scab. Journal of Agricultural and Food Chemistry 2005, 53(2):356-362.

48. Cichewicz RH, Kouzi SA: Biotransformation of resveratrol to piceid by Bacillus cereus. Journal of Natural Products 1998, 61(10):1313-1314.

49. Tuomi J, Niemela P, Siren S: The Panglossian Paradigm and Delayed Inducible Accumulation of Foliar Phenolics in Mountain Birch. Oikos 1990, 59(3):399-410.

50. Suda J, Travnicek P, Mandak B, Berchova-Bimova K: Genome size as a marker for identifying the invasive alien taxa in Fallopia section Reynoutria. Preslia 2010, 82(1):97-106.

51. Koske RE, Gemma JN: A Modified Procedure for Staining Roots to Detect Va-Mycorrhizas. Mycological Research 1989, 92:486-505.

52. Trouvelot A, Kough JL, Gianinazzi-Pearson V: Mesure du taux de mycorhization VA d'un systeme radiculaire. Recherche de m,thodes d'estimation ayant une signification fonctionelle. In Physiological and Genetical Aspects of Mycorrhizae. Edited by: Gianinazzi-Pearson V, Gianinazzi S. INRA Press: Paris; 1986:217-221.

53. Zbíral J, Urbánková E, Tieffová P, Rychlý M: Analysis of plant material (Analýza rostlinného materiálu) - in Czech. Brno: ÚKZÚZZ 2005, 192.

54. Olsen SR, Cole CV, Watanabe FS, Dean LA: Estimation of available Phosphorus in Soils by Extraction with Sodium Bicarbonate. USDA Circular No 939, Washinghton D.C 1954, 1-19.

doi:10.1186/1471-2229-11-98

Cite this article as: Kovárová et al:: Effect of clone selection, nitrogen supply, leaf damage and mycorrhizal fungi on stilbene and emodin production in knotweed. BMC Plant Biology 2011 11:98.

\section{Submit your next manuscript to BioMed Central and take full advantage of:}

- Convenient online submission

- Thorough peer review

- No space constraints or color figure charges

- Immediate publication on acceptance

- Inclusion in PubMed, CAS, Scopus and Google Scholar

- Research which is freely available for redistribution

Submit your manuscript at www.biomedcentral.com/submit
Biomed Central 